\title{
Reaction of Glossoscolecidae (Annelida, Oligochaeta) to flooding in a Central Amazonian inundation forest
}

\author{
Joachim Adis (')
}

Vera Bogen (')

\begin{abstract}
Horizontal migration in response to flooding is reported for Glossoscolecidae of a black-water inundation forest. During increasing water-level, Glossoscolecidae migrate towards the dry-land forest, $16-26 \mathrm{~m}$ distance beyond the water margin. With decreasing water-level, they return to the inundation-forest, following the water margin at $5-10 \mathrm{~m}$ distance. Distribution seems to be correlated with humidity and $\mathrm{pH}$ of the soil.
\end{abstract}

\section{INTRODUCTION}

In 1976/77, a 'minimal program for ecosystem analyses' was carried out in a black-water inundation forest $(=$ Igapó $)$ at Rio Tarumã Mirim near Manaus, Brazil (Adis, 1977, 1981) During the non-flooded period (SeptemberMarch) Glossoscolecidae - mainly Tairona tipema (Righi et al., 1976) — were sporadically caught in pitfall traps and ground photoeclectors. Some occured in arboreal photoeclectors throughout inundation. However. reaction of Glossoscolecidae to flooding remained unknown. Further investigations have now been carried out during rising and re. ceding water-level in 1981/82.

\section{STUDY AREA, METHODS}

The study area is situated at the lower course of Rio Tarumã Mirim, an affiluent of the Rio Negro, about $20 \mathrm{~km}$ upstream from Manaus. A detailed description of the area investigated is given in Adis (1981) .

Soil samples were taken in the upper, central and lower part of the Igapó: - 1) During the receding flood stage at site $\mathrm{L}_{h}$ (Fig. 1) on July 10,1981, at site $\mathrm{L}_{\mathrm{a}}$ on August
18, 1982 and $100 \mathrm{~m}$ south of site $\mathrm{L}_{\mathrm{a}}$ on August 27, 1981; - 2) During the increasing flood stage between sites $L_{a}$ and $L_{b}$ on April 06 . 1982. Additional soil samples were taken near the forest edge (150 m west of site $\mathrm{L}_{a}$ ) on October 19, 1981. At each site, five soil samples (\%: $21 \mathrm{~cm}$, depth $10 \mathrm{~cm}$ ) were collected every $5 \mathrm{~m}$ along a transect towards the dry-land forest. Samples were either taken from the water margin up to $20 \mathrm{~m}$ distance $(10.7 .81,18.8 .81)$ or $1 \mathrm{~m}$ from the water margin up to $31 \mathrm{~m}$ distance $(27.8 .81,19.10 .81$, 6.4.82). A split corer (= steel cylinder with lateral hinges) served as collecting device. It was diriven into the soil by a mallet. To avoid material decomposition, Glossoscolecidae were hand sorted from the samples in the laboratory and preserved in alcohol on the day of collection.

\section{RESULtS}

During high water-level, Glossoscclecidae were found concentrating bətween $5 \mathrm{~m}$ and $10 \mathrm{~m}$ distant from the water margin in the upper part of the forest (Fig: 2: $\mathrm{L}_{\mathrm{b}}$ ). Up to 45 specimens per sample ( $=$ about $\left.1300 / \mathrm{m}^{2}\right)$ were collected in July 1981, the majority from the $6-10 \mathrm{~cm}$ deep humus !ryer (= matting of roots with fine humus). With increasing distance from the water margin, soil humidity and $\mathrm{pH}$ decreased (Fig. 2: $\mathrm{L}_{b}$ ) and the number of Giossoscolecidae sampled dropped signifi cantly $(p<0.05)$. Only a few specimens were encountered when soil humidity was lower than $30 \%$ and soil pH below 3,6.

With receding flood, Glossoscolecidae immigrated into the Igapó, in accompanying the water Imargin (comp. Irmier, 1976). They mostly dispersed to humid places in the forest

(1) - Max-Planck-Institute for Limnology (Working Group: Tropical Ecology), D-232 Plön, West Germany, in cooperation with Instituto Nacional de Pesquisas da Amazônia, Manaus. 
(e.g. logs, roots of buttressed trees, soil depressions), where they stayed until the end of the ary season in December (comp. Adis 1981, 1982). The maximum number of Glossoscolecidae collected in the lower part of the forest in August 1981 was 22 specimens per sample ( $=$ about $635 / \mathrm{m}^{2}$ ). Most of them were found between $1 \mathrm{~m}$ and $11 \mathrm{~m}$ distant from the water margin (Figs, 2, 3). Throughout the horizontal immigration into the Igapó, single cocoons were deposited in the humus layer. The receding high water-level- reached the forest edge in October 1981, where no Glos. soscolecidae could be found in soil samples.

During the rainy season of the non-flooded pericd (December - March/April), Glossoscolecidae were colonizing the humus layer of the inundation forest. Gut contents, examined throughout the period investigated, mainly contained small roots (calyptras), small leaves (litter), tannins, few hyphae and spores of fungi and almost no soil particles (comp. Schailer 1973). In the anterior part of the digestive tract elongate-shaped bacteria (" $\mathrm{ba}$ cilli") were found; in the posterior part roundshaped bacteria ("cocci") occured (Katz, pers comm. . .

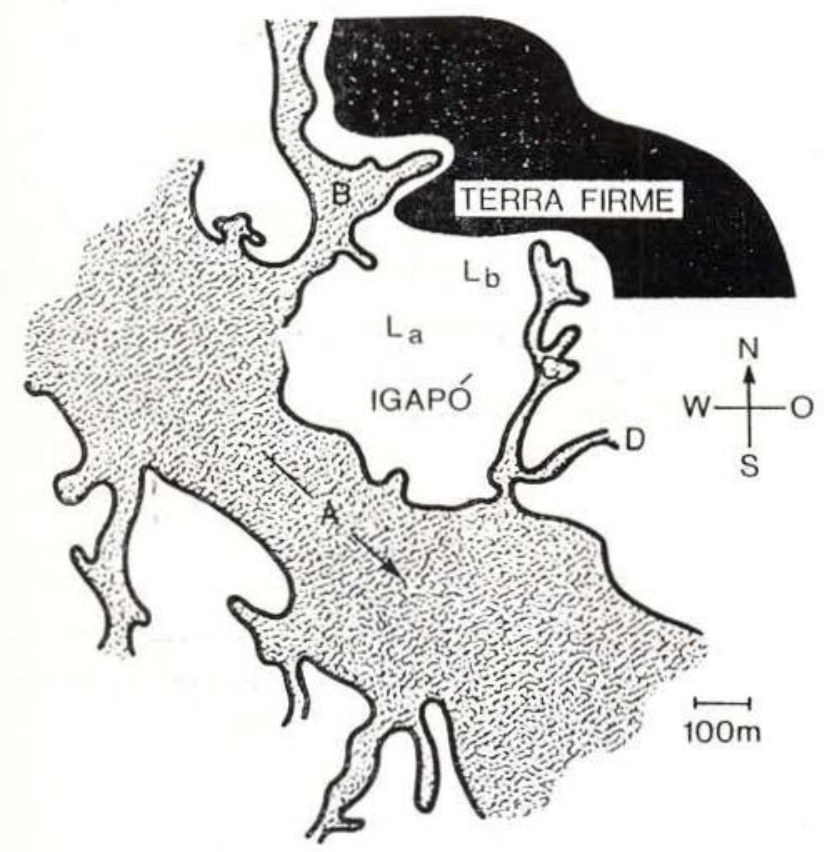

Fig. 1 - Location of the study area at Rio Tarumã-Mirim (to Adis 1981). $A=$ Rio Tarumã-Mirim, $B=$ Igarapé São João, $\mathrm{C}=$ Igarapé Nova Inveja, $\mathrm{D}=$ Igarapó Pupunha, $\mathrm{La} / \mathrm{Lb}=$ sampling sites.
With increasing water-level and subsequent forest inundation, Glossoscolecidae (including the young progeny) apparently escaped flooding, in migrating beyond the water margin towards the dry-land forest. In April 1982, up to 26 specimens per sample ( = about $750 / \mathrm{m}^{2}$ )
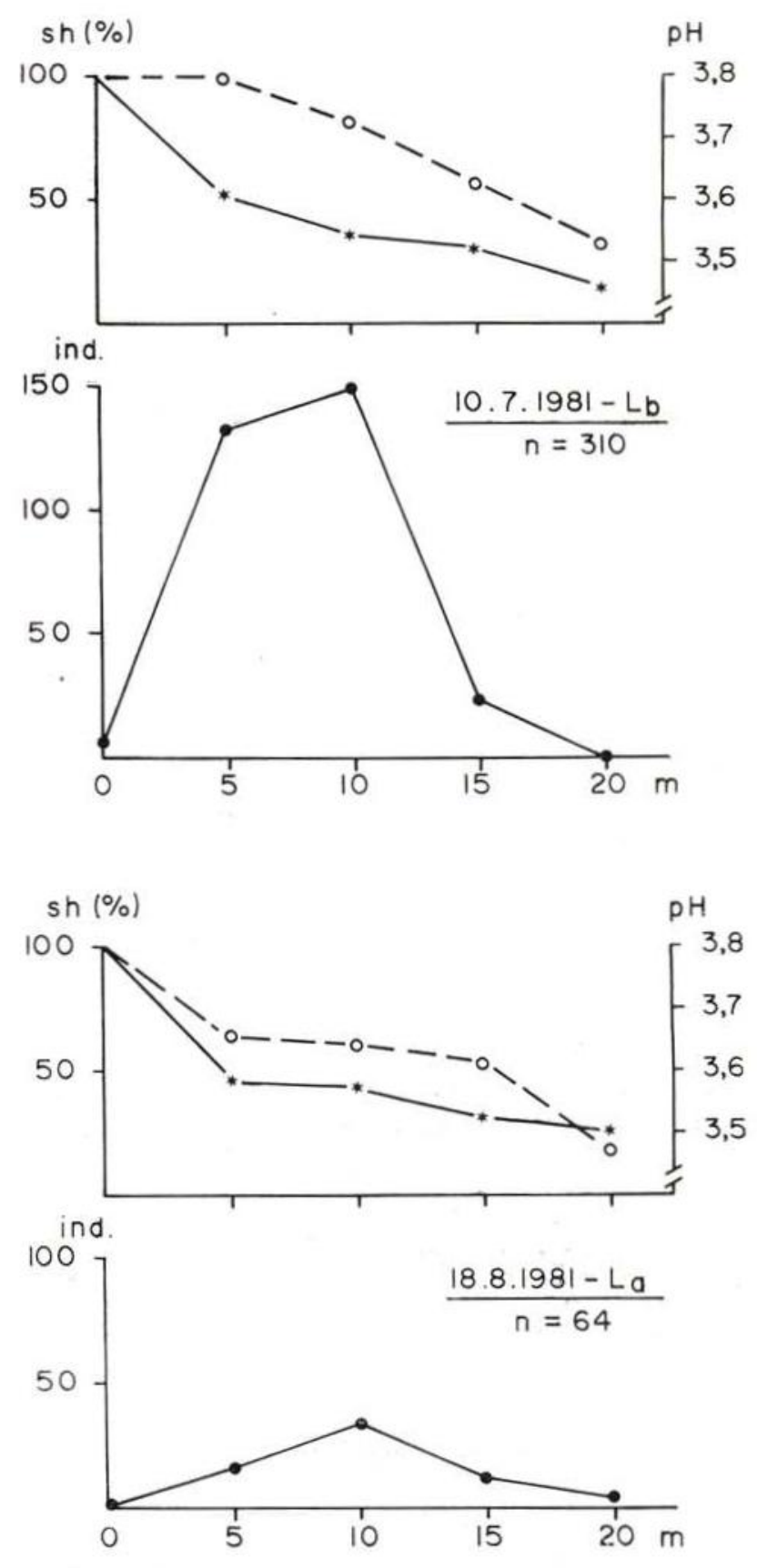

Fig. 2 - Total catch of Glossoscolecidae sampled up to $20 \mathrm{~m}$ distance from the water margin during the receding flood stage in the upper and lower part of the forest ( $\mathrm{Lb}$ and La respectively; 5 samples taken every $5 \mathrm{~m}) .{ }^{*}-{ }^{*}=$ soil humidity $(\mathrm{sh}), 0--\mathrm{o}=\mathrm{pH}$ of soil $(\mathrm{pH})$. 

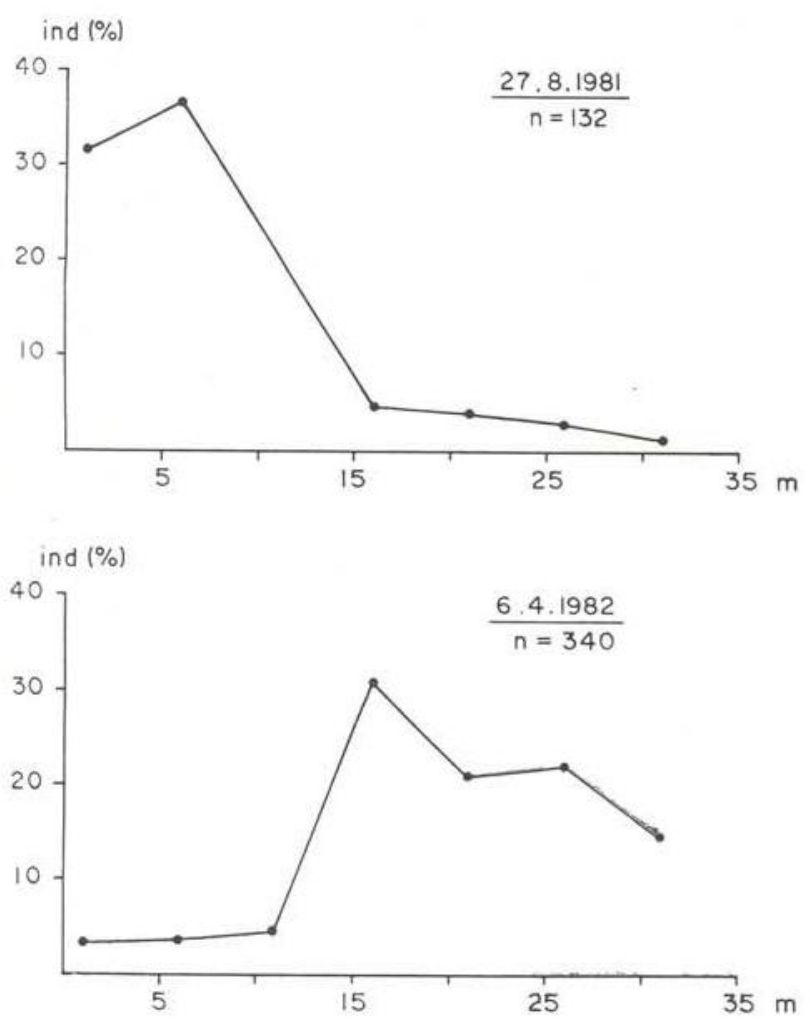

Fig. 3 - Total catch of Glossoscolecidae (in \%) sampled up to $26 \mathrm{~m}$ distance from the water margin during receding flood stage in the lower part of the forest (27.8.1981) and during increasing flood stage in the central part of the forest $(6.4 .82 ; 5$ samples taken every $5 \mathrm{~m}$ ).

were coilected in the central part of the forest. mostly 16-26 $\mathrm{m}$ distant from the water margin (Fig. 3). Some of them apparently' mount tree trunks. They were caught in arboreai photo-eclectors (Adis 1981). Others were drowned and mostly eaten by fish when appearing in the water after having emerged from the humus layer.

\section{ACKNOWLEDGMENTS}

Norman Penny (INPA) kindly reviewed the manuscript. Barry Katz (Univ. of North Carolina) helped to identify the stomach contents.
We heartily thank Nildon Pinto Ataide and Edilson de Araujo Silva (INPA) for their help received during field excursions and material sorting.

\section{RESUMO}

Migrações horizontais devido as inundações são observadas para Glossoscolecidae de um igapó na região da água preta. Durante a subida do nível da água (enchente), os Glossoscolecidae estão migrando na direção da terra firme, acompanhando a margem da água numa distância de $16 \mathrm{~m}$ até $26 \mathrm{~m}$. Durante a descida do nivel da água (vazante), eles retornam para o igapó, seguindo a margem da água numa distância de $5 \mathrm{~m}$ até $10 \mathrm{~m}$. A distribuiçäo parece estar correlacionada com a umidade e o $\mathrm{pH}$ do solo.

\section{REFERENCES}

ADIS, J.

1977 - Programa mínimo para análises de ecossıstemas: Artrópodos terrestres em florestas inundáveis da Amazônia Central. Acta Amazonica, 7 (2): 223-229.

1 1 81 - Comparative ecological Studies of the terrestrial arthropod fauna in Central Amazonian Inundation-Forests. Amazoniana, 7 (2): 87-173.

1982 - Adaptations of arthropods to Amazonian inundation-forests. Proc. Int. Soc. Trop. Ecol. (VII. Symposium, Bhopal/India 1981): in press.

IRMLER, U.

1 y76 - Zusammensetzung, Besiedlungsdichte und Biomasse der Makrofauna des Bodens in der emersen und submersen Phase zentralamazonischer Öberschwemmungswälder Biogeographica, 7: 79-99.

RIGHI, G.; AYRES, I.; BITTENCOURT, E.C.R.

1976 - Glossoscolecidae (Oligochaeta) do Instituto Nacional de Pesquisas da Amazônia. Acta Amazonica, 6 (3): 335-367.

SCHALLER, F.

1973 - Zur Ernährungsbiologie neotropischer Bodentiere. Die Naturwissenschaften, 4: 203204.

(Aceito para publicação em 22/11/82) 